\title{
Cellular characteristics of sputum from patients with asthma and chronic bronchitis
}

\author{
P G GIBSON, A GIRGIS-GABARDO, M M MORRIS, S MATTOLI, J M KAY, \\ J DOLOVICH，J DENBURG，F E HARGREAVE
}

From the Departments of Medicine, Pediatrics, and Pathology, McMaster University, and St Joseph's Hospital, Hamilton, Ontario, Canada

\begin{abstract}
The reproducibility of sputum cell counts was examined and the cell counts in patients with asthma were compared with those in patients with chronic bronchitis. Three groups of subjects were studied. Sputum from eight patients with chronic asthma and with sputum production were studied to determine the reproducibility of sputum cell counts. The findings in 10 non-smokers with asthma uncomplicated by other airway disease examined at the time of an exacerbation with sputum (group 2) were compared with those from eight smokers with chronic cough and sputum but no features of asthma (group 3). Sputum plugs were selected by microscopy to ensure their origin from the lower respiratory tract. A total cell count was performed on a trypsinised suspension, and differential and metachromatic cell counts were performed on undiluted plugs. The within specimen and test-retest reproducibility of these measurements was high (reliability coefficient, $R,=0.99$ and $0.89)$. The sputum of the asthmatic patients was characterised by eosinophilia (69\%, range 46-92\%) and the presence of formaldehyde blockable metachromatic cells $(1 \cdot 5 \%$, range $0.6-2 \cdot 8 \%)$. In comparison, the sputum of the patients with chronic bronchitis had few eosinophils $(0.5 \%)$ or metachromatic cells $(0 \cdot 14 \%)$; the dominant cell type was the macrophage $(83 \%)$. It is concluded that sputum cell counts are reproducible in the short term, the inflammation of asthma is characterised by eosinophilia and metachromatic cells in sputum, and sputum may provide a useful source of cells for investigating the cellular characteristics of airway inflammation.
\end{abstract}

\section{Introduction}

Airway inflammation is important in the pathology of asthma, consisting of eosinophilic infiltrates, epithelial damage, and mucus plugging. ${ }^{\prime}$ In clinically stable patients bronchoscopy has been used to study airway inflammation, ${ }^{23}$ but an increased risk limits the use of this technique in patients with an exacerbation. A noninvasive technique such as sputum analysis could provide an alternative method to study the cellular pathology of asthma during an exacerbation.

Sputum eosinophilia has been reported to be a characteristic feature of asthma ${ }^{4-6}$ and "basophils" have been observed in the sputum of some patients with asthma ${ }^{6}$; other authors, however, have described sputum eosinophilia in chronic bronchitis. ${ }^{7-9}$ This discrepancy may be due to diversity in the clinical characterisation of subjects or the methods used for

\footnotetext{
Address for reprint requests: Dr F E Hargreave, Firestone Regional Chest and Allergy Unit, St Joseph's Hospital, Hamilton, Ontario, Canada L8N 4A6.
}

Accepted 9 June 1989 sputum analysis. We have therefore examined the reproducibility of sputum cell counts and compared the sputum cell counts of non-smokers with an exacerbation of asthma with those of smokers with chronic bronchitis, paying careful attention to the selection and classification of subjects.

\section{Methods}

\section{SUBJECTS}

Three groups of adults were selected, the first two being from St Joseph's Hospital. Eight adults with regular daily sputum (group 1) were studied to determine the reproducibility of sputum cell counts and were selected solely by their willingness to bring the first specimen of sputum expectorated on each of two consecutive days. All were considered to have asthma, and were receiving corticosteroids. There was chronic airflow limitation in seven.

Group 2 comprised 10 non-smoking adults seen in the clinic who were experiencing an exacerbation of asthma associated with a productive cough; they were not receiving treatment with corticosteroids or sodium 
Table 1 Characteristics of the subjects in group 2 (asthma) and group 3 (chronic bronchitis)

\begin{tabular}{|c|c|c|c|c|c|c|}
\hline $\begin{array}{l}\text { Subject } \\
\text { No }\end{array}$ & $\begin{array}{l}\text { Age } \\
(y)\end{array}$ & Sex & $\begin{array}{l}\text { Baseline \%FEV, } \\
\left(F E V_{1} / V C \%\right)\end{array}$ & $\begin{array}{l}P C_{20} \\
(m g / m l)\end{array}$ & $\begin{array}{l}\text { Post-treatment }{ }_{+}^{+} \\
\% F E V_{1}\left(F E V_{1} / V C \%\right)\end{array}$ & Atopy $\dagger$ \\
\hline \multicolumn{7}{|l|}{ Group 2} \\
\hline $\begin{array}{r}1 \\
2 \\
3 \\
4 \\
5 \\
6 \\
7 \\
8 \\
9 \\
10\end{array}$ & $\begin{array}{l}61 \\
67 \\
61 \\
21 \\
61 \\
38 \\
70 \\
44 \\
26 \\
46\end{array}$ & $\begin{array}{l}\mathbf{F} \\
\mathbf{M} \\
\mathbf{F} \\
\mathbf{M} \\
\mathbf{M} \\
\mathbf{M} \\
\mathbf{F} \\
\mathbf{F} \\
\mathbf{F} \\
\mathbf{M}\end{array}$ & $\begin{aligned} 86 & (64) \\
57 & (57) \\
110 & (83) \\
53 & (59) \\
58 & (45) \\
38 & (36) \\
111 & (68) \\
75 & (65) \\
87 & (87) \\
67 & (63)\end{aligned}$ & $\begin{array}{l}0.09 \\
0.15 \\
1.37 \\
0.14 \\
<0.03 \\
<0.03 \\
3.7 \\
0.09 \\
0.82 \\
0.06\end{array}$ & $\begin{aligned} 93 & (78) \\
72 & (70) \\
119 & (85) \\
96 & (76) \\
110 & (72) \\
85 & (76) \\
118 & (78) \\
93 & (78) \\
101 & (88) \\
106 & (88)\end{aligned}$ & $\begin{array}{r}0 \\
2 \\
0 \\
4 \\
3 \\
11 \\
7 \\
8 \\
1 \\
6\end{array}$ \\
\hline $\begin{array}{l}\text { Mean } \\
\text { SEM }\end{array}$ & $\begin{array}{l}49 \\
5 \cdot 4\end{array}$ & & $83(63)$ & $0.182^{*}$ & $99(79)$ & \\
\hline \multicolumn{7}{|l|}{ Group 3} \\
\hline $\begin{array}{l}1 \\
2 \\
3 \\
4 \\
5 \\
6 \\
7 \\
8\end{array}$ & $\begin{array}{l}60 \\
59 \\
48 \\
58 \\
45 \\
45 \\
63 \\
47\end{array}$ & $\begin{array}{l}\mathbf{M} \\
\mathbf{F} \\
\mathbf{M} \\
\mathbf{M} \\
\mathbf{M} \\
\mathbf{M} \\
\mathbf{M} \\
\mathbf{F}\end{array}$ & $\begin{aligned} 81 & (70) \\
105 & (70) \\
95 & (71) \\
87 & (71) \\
94 & (74) \\
78 & (72) \\
97 & (72) \\
95 & (93)\end{aligned}$ & $\begin{array}{c}256 \\
8 \cdot 6 \\
74 \cdot 3 \\
>256 \\
10 \cdot 6 \\
12 \cdot 0 \\
57 \cdot 2 \\
24\end{array}$ & $\begin{aligned} 70 & (74) \\
110 & (76) \\
97 & (73) \\
90 & (71) \\
90 & (79) \\
79 & (72) \\
105 & (78) \\
94 & (88)\end{aligned}$ & $\begin{array}{l}0 \\
0 \\
0 \\
0 \\
5 \\
0 \\
0 \\
0\end{array}$ \\
\hline $\begin{array}{l}\text { Mean } \\
\text { SEM }\end{array}$ & $\begin{array}{l}53 \\
2 \cdot 4\end{array}$ & & $\begin{array}{l}92(74) \\
3 \cdot 2(2 \cdot 8)\end{array}$ & $40 \cdot 55^{*}$ & $92(76)$ & \\
\hline
\end{tabular}

$\% \mathrm{FEV}_{1}-\mathrm{FEV}_{1}$ as $\%$ predicted; $\mathrm{PC}_{20}$ - provocation concentration of methacholine producing a $20 \%$ fall in $\mathrm{FEV}_{1}$.

*Geometric mean.

† Number of positive skinprick test responses to 12 common allergen extracts.

†After two weeks' inhaled corticosteroid.

cromoglycate (table 1). The evidence for asthma was a history of episodic dyspnoea with wheeze and variable airflow limitation as judged by an improvement of over $20 \%$ in $\mathrm{FEV}_{1}$ after bronchodilator treatment or by airway hyperresponsiveness to methacholine. ${ }^{10}$ Subsequent treatment with corticosteroids led to complete resolution of sputum production and airflow limitation in these subjects.

Group 3 consisted of eight current cigarette smokers (who had smoked for a mean of 38 (SD 5) pack years), who had volunteered to participate in research in response to a newspaper article. They had a productive cough on most mornings for more than three months for two consecutive years and no history of asthma. They were not receiving medication and had an FEV above $80 \%$ predicted and an $\mathrm{FEV}_{1} / \mathrm{VC}$ of over $70 \%$, an increase in $\mathrm{FEV}_{1}$ of under $15 \% 15$ minutes after receiving $200 \mu \mathrm{g}$ salbutamol, and normal methacholine airway responsiveness (table 1 ). When they were treated with inhaled beclomethasone dipropionate $200 \mu \mathrm{g}$ twice daily for two weeks there was no change in sputum production or in spirometric values.

All subjects in groups 2 and 3 had a normal chest radiograph. None had purulent sputum (grade P3) or a positive sputum culture, and none required treatment with antibiotics either in the month before or during the study.

The study was approved by the hospital research committee and all subjects gave written informed consent.

\section{STUDY DESIGN}

The first sputum produced after waking in the morning was brought to the laboratory for examination within three hours. For seven subjects from group 1 and seven from group 3 this was carried out on two consecutive days to establish the test-retest reproducibility of sputum cell counts. In group 2 (asthma) and group 3 (smokers) clinical characteristics were documented by questionnaire, and skinprick tests with 12 common allergen extracts, spirometry, and a methacholine inhalation test were carried out. The bronchodilator response to salbutamol was measured in group 3 when sputum was brought on the second day. After sputum collection subjects in groups 2 and 3 were treated with inhaled beclomethasone dipropionate $200 \mu \mathrm{g}$ twice daily, with the exception of two asthmatic patients who received $400 \mu \mathrm{g}$ twice daily and one who received an additional 10 day course of oral prednisone. Care was taken to teach and check the correct technique of inhaler use, and compliance was checked by measurement of canister weights. All subjects were evaluated after two weeks' treatment by a symptom questionnaire and repeat spirometry.

\section{CLINICAL METHODS}

Spirometry was performed with a Collins 9 litre water sealed spirometer.

Methacholine inhalation tests were performed by the method described by Cockcroft et al, ${ }^{10}$ modified in two ways: the concentration of methacholine was 
increased to $256 \mathrm{mg} / \mathrm{ml}$ if necessary, and the test aerosol was delivered to the subject through a three way Hans-Rudolph valve box and mouthpiece. The results were expressed as the provocation concentration required to cause a fall in $\mathrm{FEV}_{1}$ of $20 \%\left(\mathrm{PC}_{20}\right)$; values below $8 \mathrm{mg} / \mathrm{ml}$ are regarded as being in the asthmatic range.

\section{SPUTUM EXAMINATION}

Sputum volume was recorded and the sample transferred to a petri dish, where its macroscopic characteristics were recorded. Two plugs free of salivary contamination were identified by means of an inverted microscope. A portion of each plug was suspended in $0.5 \mathrm{ml}$ phosphate buffered saline (PBS) and buffered crystal violet and a second portion placed in $0.5 \mathrm{ml}$ trypsin-EDTA and incubated for two hours at $37^{\circ} \mathrm{C}$, after which buffered crystal violet was added. A total cell count was performed on each suspension with a haemocytometer. Additional portions from each plug were then smeared on to five slides and air dried. From each plug two slides were fixed with methanol and stained with May-Grünwald-Giemsa and three slides were fixed with either Carnoy's fluid (two slides) or $10 \%$ formalin (one slide) and stained with $0.5 \%$ toluidine blue in $0.7 \mathrm{M} \mathrm{HCl}$ at $\mathrm{pH} 0.1$. The slides were coded and the cells counted by one of two investigators unaware of the clinical characteristics of the subjects. A differential cell count of intact bronchial epithelial cells and leucocytes was obtained for each plug by counting at least 400 cells on each of the two slides stained with May-Grünwald-Giemsa; the results were expressed as a percentage of the total cells counted on both slides. In each slide stained with toluidine blue 1500 nucleated cells were counted and the number of metachromatic cells (mast cells and basophils) was expressed as a percentage of the total cells. In each slide cells were counted in at least 20 randomly selected high power $(\times 500)$ fields of comparable cell density in which no squamous epithelial cells were present and in which most cells appeared intact. Metachromatic cells were examined on slides stained with toluidine blue after Carnoy's fixation under $\times 1250$ magnification and classified by morphological criteria ${ }^{11}$ as basophils ( $<10 \mu \mathrm{m}$, lobulated nucleus), mast cells $(>10 \mu \mathrm{m}$, round nucleus), small mast cells $(<10 \mu \mathrm{m}$, round nucleus), or unclassified metachromatic cells. This classification has previously been applied to metachromatic cells from nasal secretions and the light microscopic descriptions have been found to correspond to electron microscopic classification of these cells. ${ }^{11} 12$ The presence of metachromatically staining mucus in 10 randomly selected low power fields $(\times 31)$ from slides stained with toluidine blue was assessed; such material is usually due to acid glycoprotein in the mucus. ${ }^{12}$

\section{STATISTICAL ANALYSIS}

Cell counts were expressed as arithmetic means with standard errors in parentheses. $\mathrm{PC}_{20}$ results were log transformed for analysis. The reproducibility of sputum cell counts was examined by one way analysis of variance with calculation of the coefficient of reliability $(R)^{14}$ - the ratio of the variance of cell counts within subjects to the total variance in cell counts (subject and error variance), higher values indicating higher reliability. To examine the within specimen reproducibility of cell counts, $\mathbf{R}$ was calculated for the cell counts obtained for each sputum plug and the testretest reproducibility from sputum submitted on two consecutive days. Observer variation for differential cell counts performed on 15 coded slides by each of the two investigators was assessed; $R$ was greater than 0.7 for each of the cell types enumerated. Sputum cell counts are reported as the mean value of the results from the two plugs examined in each sample. Two tailed unpaired $t$ tests were used to compare results between group 2 (asthmatic subjects) and group 3 (smokers). Proportional data were compared on the basis of the normal approximation of the binomial distribution and correlations were examined by least squares linear regression analysis. Significance was accepted at the $95 \%$ level.

Table 2 Reliability of sputum cell counts*

\begin{tabular}{|c|c|c|c|c|c|c|c|c|}
\hline \multirow[b]{2}{*}{$\begin{array}{l}\text { Cell counts } \\
\text { examined }\end{array}$} & \multicolumn{2}{|c|}{ Total cell count } & \multicolumn{6}{|c|}{ Cellular differential ${ }^{* *}$} \\
\hline & $P B S$ & Trypsin§ & $\begin{array}{l}\text { Metachromatic } \\
\text { cells }\end{array}$ & Eosinophils & $\begin{array}{l}\text { Epithelial } \\
\text { cells }\end{array}$ & Neutrophils & Lymphocytes & Macrophages \\
\hline $\begin{array}{l}\text { Within sample } \dagger \\
\text { Day to day } \ddagger\end{array}$ & $\begin{array}{l}0.89 \\
0.77\end{array}$ & $\begin{array}{l}0.99 \\
0.89\end{array}$ & $\begin{array}{l}0.95 \\
0.94\end{array}$ & $\begin{array}{l}0.97 \\
0.96\end{array}$ & $\begin{array}{l}0.73 \\
0.76\end{array}$ & $\begin{array}{l}0.92 \\
0.90\end{array}$ & $\begin{array}{l}0.86 \\
0.68\end{array}$ & $\begin{array}{l}0.90 \\
0.94\end{array}$ \\
\hline
\end{tabular}

* Coefficient of reliability ( $R$ ) for sputum cell counts.

PBS-phosphate buffered saline sputum suspension.

**Metachromatic cells were counted from slides stained with toluidine blue pH $0 \cdot 1$ after Carnoy's fixation; the remainder of cells in the differential count were counted on May-Grünwald-Giemsa stained slides.

+Values for two plugs from the same sample. §Trypsinised sputum suspension.

$\ddagger$ Values for two sputum samples from consecutive days (test-retest reliability). 

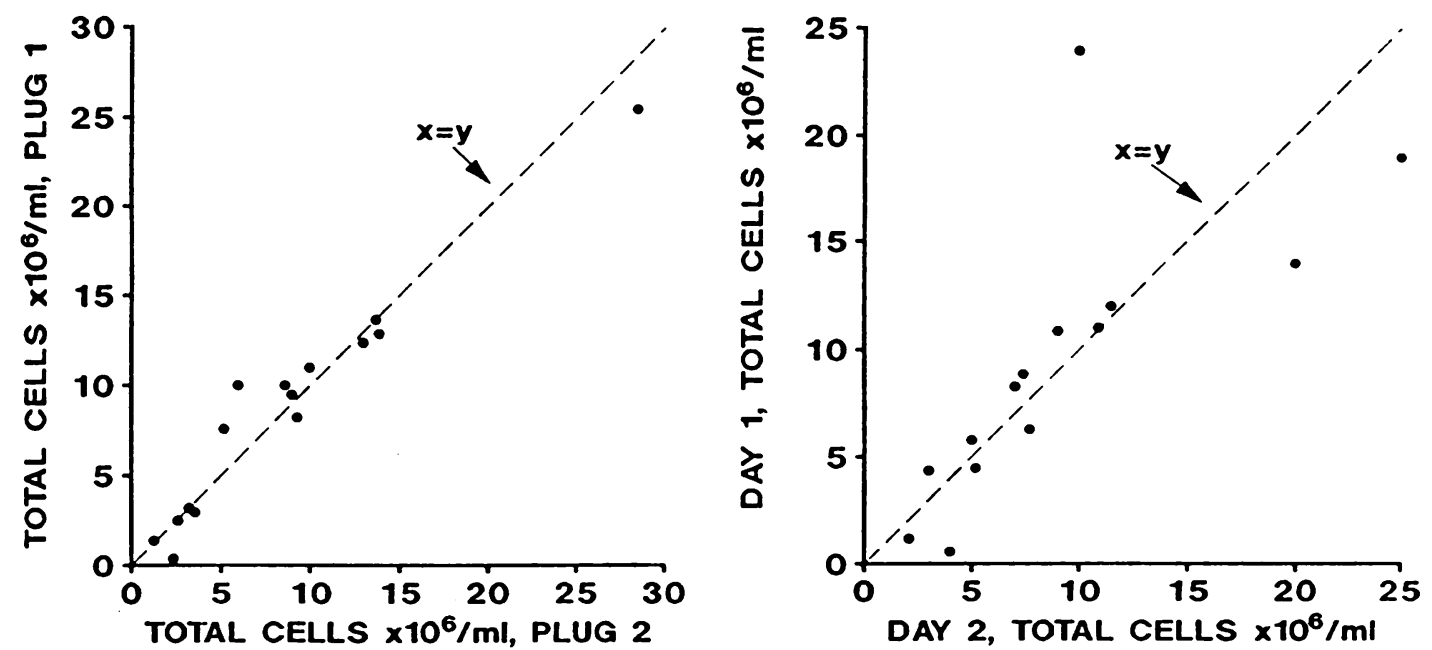

Fig 1 Identity plots of sputum total cell counts obtained from two plugs of the same specimen (left) and from specimens collected from the same subject on two consecutive days (right) (seven subjects from group 1 and seven from group 3 ).

\section{Results}

\section{REPRODUCIBILITY OF SPUTUM CELL COUNTS}

There was good reproducibility of within specimen sputum total cell counts for both the PBS suspension $(R=0.89)$ and the trypsinised suspension $(R=0.99)$ (table 2, fig 1). The reproducibility of sputum total cell counts obtained from samples collected from the same patient on two consecutive days (test-retest reproducibility) was also high for both PBS
$(R=0.77)$ and trypsinised suspensions $(R=0.89)$ (table 2, fig 1).

To examine the reproducibility of sputum differential cell counts, the reliability coefficient was calculated for each cell type enumerated. There was high reproducibility for the differential cell counts from two plugs from the same specimen $(R>0.7$ for all cell types) and from specimens collected on consecutive days ( $R>0.7$ for all cell types) (table 2$)$. In particular, the reproducibility of eosinophil and metachromatic
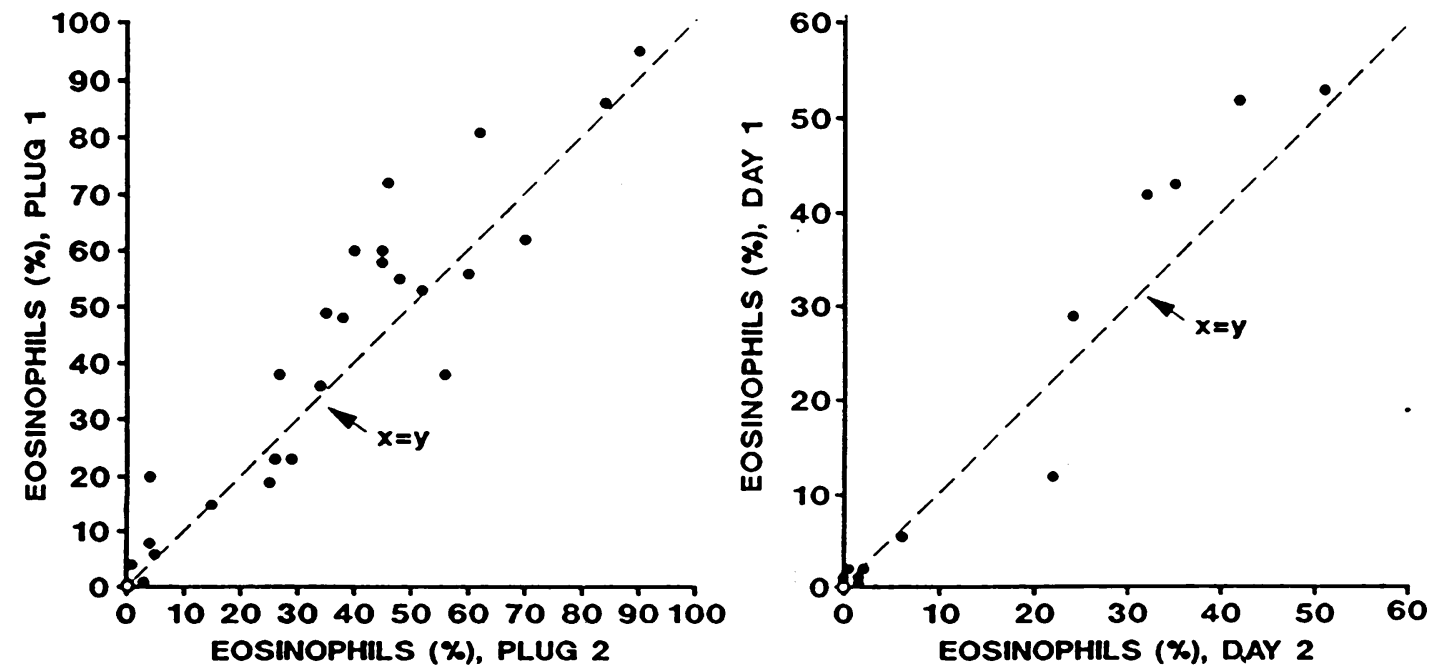

Fig 2 Identity plots of the percentages of eosinophils in sputum (left) for two plugs of the same specimen from subjects in groups 1,2, and 3 (o represents values of 15 specimens) and (right) for specimens collected on two consecutive days from 7 subjects from group 1 and seven from group 3 (o represents values of two subjects). 
Table 3 Sputum cell counts from group 2 (subjects with an exacerbation of asthma) and group 3 (smokers with chronic bronchitis)

\begin{tabular}{|c|c|c|c|c|c|c|c|}
\hline \multirow[b]{2}{*}{$\begin{array}{l}\text { Subject } \\
\text { No }\end{array}$} & \multirow{2}{*}{$\begin{array}{l}\text { Total } \\
\text { cell count } \dagger \\
\left(\times 10^{6} / \mathrm{ml}\right)\end{array}$} & \multicolumn{6}{|c|}{ Cellular differential (\%) $\ddagger$} \\
\hline & & $\begin{array}{l}\text { Bronchial } \\
\text { epithelial cells }\end{array}$ & Neutrophils & Lymphocytes & Macrophages & Eosinophils & $\begin{array}{l}\text { Metachromatic } \\
\text { cells }\end{array}$ \\
\hline $\begin{array}{c}\text { Group } 2 \\
1 \\
2 \\
3 \\
4 \\
5 \\
6 \\
7 \\
8 \\
9 \\
10\end{array}$ & $\begin{array}{r}1 \cdot 6 \\
2 \cdot 5 \\
8 \cdot 5 \\
3 \cdot 2 \\
9 \cdot 5 \\
5 \cdot 2 \\
20 \cdot 5 \\
6 \cdot 5 \\
4 \cdot 8 \\
23 \cdot 4\end{array}$ & $\begin{array}{r}2 \cdot 50 \\
6 \cdot 17 \\
23 \cdot 20 \\
4 \cdot 59 \\
1 \cdot 25 \\
24 \cdot 22 \\
19 \cdot 62 \\
12 \cdot 25 \\
20 \cdot 00 \\
11 \cdot 24\end{array}$ & $\begin{array}{l}0.06 \\
2 \cdot 74 \\
3.88 \\
0 \\
0 \\
2.59 \\
5.06 \\
1.68 \\
5.0 \\
0\end{array}$ & $\begin{array}{l}0.40 \\
1.58 \\
3.23 \\
0.85 \\
0.52 \\
0.36 \\
1.30 \\
3.59 \\
2.40 \\
2.05\end{array}$ & $\begin{array}{r}5 \cdot 39 \\
18 \cdot 22 \\
11 \cdot 13 \\
9 \cdot 70 \\
4 \cdot 40 \\
11 \cdot 20 \\
32 \cdot 71 \\
32 \cdot 66 \\
5 \cdot 00 \\
20 \cdot 31\end{array}$ & $\begin{array}{l}91 \cdot 60 \\
71 \cdot 37 \\
58 \cdot 38 \\
84 \cdot 30 \\
92 \cdot 50 \\
59 \cdot 21 \\
50 \cdot 47 \\
46 \cdot 77 \\
66 \cdot 30 \\
66 \cdot 49\end{array}$ & $\begin{array}{l}0.90 \\
2.24 \\
0.62 \\
1.47 \\
2.07 \\
2.11 \\
2.80 \\
0.91 \\
1.30 \\
0.71\end{array}$ \\
\hline Mean (SEM) & $8.5(2.4)$ & $12 \cdot 50(2 \cdot 7)$ & $2 \cdot 10(\cdot 65)$ & $1.63(.37)$ & $15 \cdot 07(3 \cdot 38)$ & $68 \cdot 74(5 \cdot 13)$ & $1 \cdot 51(\cdot 24)$ \\
\hline $\begin{array}{l}\text { Group } 3 \\
1 \\
2 \\
3 \\
4 \\
5 \\
6 \\
7 \\
8\end{array}$ & $\begin{array}{r}5 \cdot 2 \\
7 \cdot 0 \\
15 \cdot 1 \\
17 \cdot 5 \\
4 \cdot 9 \\
7 \cdot 5 \\
11 \cdot 1 \\
5 \cdot 0\end{array}$ & $\begin{array}{r}6 \cdot 25 \\
15 \cdot 15 \\
20 \cdot 15 \\
7 \cdot 15 \\
13.05 \\
10 \cdot 20 \\
11.00 \\
7.05\end{array}$ & $\begin{array}{l}8 \cdot 20 \\
7 \cdot 35 \\
1 \cdot 27 \\
6 \cdot 14 \\
1.50 \\
1 \cdot 35 \\
0.50 \\
5.62\end{array}$ & $\begin{array}{l}0.25 \\
0.70 \\
0.65 \\
1.28 \\
1.35 \\
0.16 \\
1.10 \\
1.73\end{array}$ & $\begin{array}{l}83 \cdot 00 \\
76 \cdot 50 \\
75 \cdot 35 \\
83 \cdot 00 \\
83 \cdot 21 \\
88 \cdot 25 \\
85 \cdot 00 \\
85 \cdot 42\end{array}$ & $\begin{array}{l}1.94 \\
0.35 \\
0.2 \\
1.22 \\
0.35 \\
0 \\
0.03 \\
0.18\end{array}$ & $\begin{array}{l}0.29 \\
0 \\
0.18 \\
0.23 \\
0.08 \\
0.2 \\
0.03 \\
0.17\end{array}$ \\
\hline Mean (SEM) & $9 \cdot 2(1 \cdot 7)$ & $11.25(1.63)$ & $3.99(1 \cdot 1)$ & $.90(\cdot 2)$ & $82.5(1.6)^{*}$ & $0.5(0.2)^{*}$ & $0.14(0.04)^{*}$ \\
\hline
\end{tabular}

${ }^{*} \mathrm{p}<0.01$.

†From a trypsinised suspension.

$\ddagger$ Metachromatic cells enumerated from Carnoy’s fixed, toluidine blue stained smears; the remainder of the cells were enumerated from MayGrünwald-Giemsa stained smears.

cell counts was high, both within specimens $(R=0.97$ eosinophils, $R=0.95$ metachromatic cells) and between two consecutive specimens from the same patient $(R=0.96$ eosinophils, $R=0.94$ metachromatic cells) (table 2, fig 2).

\section{COMPARISON OF SPUTUM CELL COUNTS IN}

\section{ASTHMATIC PATIENTS AND SMOKERS}

Sputum from the patients in group 2 (asthma) differed from that from patients in group 3 (smokers) with respect to the number of eosinophils and metachromatic cells, the number and morphological appearance of macrophages, and the staining properties of the background mucus (table 3 ).

In group $268.7 \%(5.1 \%)$ of the cells were eosinophils compared with $0.53 \%(0.24 \%)$ in smokers (p < 0.01). Metachromatic cells comprised $1.52 \%$ $(0.24 \%)$ of the cells, compared with $0.14 \%(0.04 \%)$ in smokers $(\mathrm{p}<0.01)$. Most of the eosinophils had the morphology of peripheral blood eosinophils, with a typical bilobed nucleus. A second type of eosinophil, however, with a single round or oval nucleus was also seen in nine of 10 patients in group 2. Many, but not all, of these resembled mature eosinophils in size but had pyknotic nuclei; they were not seen in the smokers $(\mathrm{p}<0.01)$.

There was no correlation between the percentage of eosinophils or metachromatic cells and pretreatment
$\mathrm{FEV}_{1}$ (\% predicted), $\mathrm{FEV}_{1} / \mathrm{VC} \%$, or $\mathrm{PC}_{20}$ in the subjects in group $2(p>0.05)$.

The dominant cell in the smokers was the macrophage, comprising $82.5 \%(1.6 \%)$ of the total cells, compared with $15.2 \%(3.4 \%)$ in group $2(p<0.01)$. The macrophages from the smokers were larger, their cytoplasm was basophilic with May-GrünwaldGiemsa stain, and multinucleate cells were frequent. In unstained preparations the macrophages of the smokers had cytoplasmic inclusions pigmented with pale yellow. Metachromatic staining of the background mucus, suggesting an increase in acidic glycoproteins, was present more frequently in sputum smears from group 3 (smokers) than from group 2 (asthma) (p < $0.05)$.

There were no significant differences between groups 2 and 3 in sputum total cell counts, intact bronchial epithelial cells, lymphocytes, or polymorphonuclear neutrophils. Curshmann's spirals and Creola bodies were noted in some patients in group 2.

\section{METACHROMATIC CELL MORPHOLOGY AND HISTOCHEMISTRY}

Most metachromatic cells from patients in groups 2 and 3 lost their metachromatic staining properties after fixation in formaldehyde ("formalin sensitive" metachromatic cells). ${ }^{12}$ The percentage of cells that retained metachromatic staining after formaldehyde 
Table 4 Morphology of metachromatic cells in sputum from subjects in group 2 (exacerbation of asthma) and group 3 (smokers with chronic bronchitis) and in nasal secretions from subjects with allergic rhinitis ${ }^{\prime 2}$ (mean (SEM) values)

\begin{tabular}{|c|c|c|c|c|}
\hline \multirow[b]{2}{*}{ Group } & \multicolumn{4}{|c|}{ Metachromatic cell differential $(\%) \ddagger$} \\
\hline & Mast cell & Small mast cell & Basophil & Unclassified metachromatic cell \\
\hline $\begin{array}{l}\text { Asthma } \dagger \\
\text { Chronic bronchitis } \dagger \\
\text { Allergic rhinitis }{ }^{16}\end{array}$ & $\begin{array}{ll}45 \cdot 0 & (8.4)^{*} \\
91 & (6.4) \\
15 & \end{array}$ & $\begin{array}{cl}50 \cdot 1 & (8 \cdot 1)^{*} \\
9 \cdot 0 & (6 \cdot 4) \\
45 & \end{array}$ & $\begin{array}{cc}4 \cdot 4 & (4 \cdot 7) \\
0 & \\
40 & \end{array}$ & $\begin{array}{ll}0 \cdot 5 & (0 \cdot 3) \\
0 & \\
0 & \end{array}$ \\
\hline
\end{tabular}

$* \mathrm{p}<0.01$, asthma $v$ chronic bronchitis.

tCurrent study.

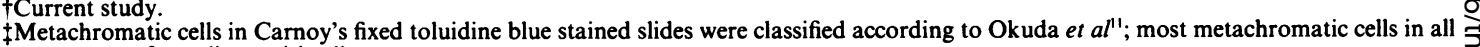
groups were "formalin sensitive."

fixation ("formalin resistant" metachromatic cells ${ }^{16}$ ) was the same in both groups (group $20.06(0 \cdot 2)$, group $30.06(0.03)$. Most of the metachromatic cells from both groups had the light microscopic characteristics of mast cells (table 4). Basophils were seen in only one subject (No 6) in group 2, comprising 33\% of metachromatic cells. There was considerable heterogeneity in the size of the mast cells from the subjects in group 2; half were classified as small mast cells, in comparison with $9 \%$ in the smokers $(p<0.001)$ (table 4$)$.

\section{Discussion}

This study shows that reproducible quantitative sputum cell counts can be obtained, and that the cellular characteristics of the sputum from carefully characterised subjects with asthma are distinct from those of smokers with chronic non-obstructive bronchitis. Sputum from asthmatic patients contains eosinophils and formalin sensitive metachromatic cells with the features of mast cells. These observations imply that sputum examination can be used to study the pathogenesis of asthma.

Previous reports of sputum cytology have established the importance of adequate sample collection and of microscopic selection of the plug for analysis to confirm that the plug consists of lower respiratory tract secretions rather than saliva. ${ }^{15}$ This was confirmed in the current study by examination during inverted microscopy, the total cell count, and study of the May-Grünwald-Giemsa stained smear. With these techniques we could formally document reproducible sputum cell counts. Asthmatic sputum is composed of glandular secretions, vascular transudate, and cells. The cellular component of mucus plugs broadly resembles that seen in the bronchial mucosa, ${ }^{1}$ in particular in the presence of eosinophils in both sites.' This suggests that examination of the type of cellular infiltrate in the sputum gives a valid representation of that present in the bronchial mucosa but does not imply that sputum necessarily reflects other facets of the airway inflammatory process.

Each of the patients with an exacerbation of asthma (group 2) had intense sputum eosinophilia and large numbers of metachromatic cells. The percentage of eosinophils, ranging from $46 \%$ to $92 \%$ of all cells, is $\vec{c}$ higher than previously reported..$^{45}$ The percentages of 8 sputum eosinophils and metachromatic cells are also $\omega$

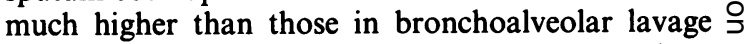
fluid from subjects with well controlled asthma, where $\vec{c}$ both eosinophils and metachromatic cells comprise $\mathbb{D}$ less than $0.5 \%$ of all cells. ${ }^{23}$ The higher counts in this $\frac{7}{\vec{D}}$ study may indicate that sputum more accurately 3 reflects the disease located in the airways than does $\underset{\mathbb{D}}{ }$ bronchoalveolar lavage fluid. Alternatively, counts may be higher owing to the fact that these patients were studied during a period of exacerbation.

The morphology of the sputum eosinophils differed from those in peripheral blood in that mononuclear eosinophils were seen in most samples from subjects in group 2. These cells have been noted in postmortem $\stackrel{2}{\circ}$ specimens from asthmatic patients, ${ }^{16}$ and although $\stackrel{\varnothing}{\AA}$ many have features suggesting cellular degeneration $\overrightarrow{\vec{A}}$ some do not. It is therefore not clear whether these $\frac{3}{3}$ cells are immature, activated, or altered by the microenvironment, ${ }^{17}$ or represent an in vitro artefact.

The metachromatic cells in asthmatic sputum had the morphological features of mast cells when examined by light microscopy; basophils were recog- $\underset{x}{x}$ nised in only one subject. These results apparently $\frac{0}{3}$ differ from those of Kimura, who reported "baso- 3 phils" in sputum, ${ }^{6}$ though in that study the criteria $\delta$ used for cell classification were not clear. The almost 3 complete absence of basophils in sputum contrasts 윽 with their predominance in nasal secretions in allergic rhinitis, where basophils comprise $40-80 \%$ of metachromatic cells $^{112}$ (table 4). Although the reasons for this difference are not clear, one possibility is that the local tissue environment may influence the type of $N$ metachromatic cell found in tissue sites, ${ }^{17}$ especially as $\underset{\omega}{N}$ locally derived growth and differentiation factors for 0 eosinophils and metachromatic cells are a feature of 0

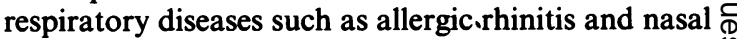
polyposis. ${ }^{18}$

There was also great variation in the size of the $T$ metachromatic cells, many small mast cells being present. This heterogeneity of size has been reported $\stackrel{\mathbb{Q}}{\square}$ previously in studies of enzymatically dispersed $\stackrel{\mathbb{Q}}{\varrho}$ human lung mast cells ${ }^{19}$ and of nasal secretion metachromatic cells in allergic rhinitis. ${ }^{112}$ A recent ultra- 
structural study ${ }^{20}$ has described mast cells during regranulation that have features consistent with the small mast cell reported here. Thus the small mast cells seen in asthmatic sputum may represent regranulating mast cells and their greater number in asthmatic patients is consistent with mast cell degranulation in asthma.

Sputum metachromatic cells were predominantly formalin sensitive, as in the nasal secretions and scrapings from patients with allergic rhinitis. ${ }^{12}$ Similar numbers of formalin resistant metachromatic cells have been described in formaldehyde fixed bronchial biopsy specimens from patients with asthma and chronic bronchitis, ${ }^{13}$ but formalin sensitive metachromatic cells in biopsy specimens have not been examined. ${ }^{12}$

The absence of a correlation between metachromatic cell counts and the degree of airflow obstruction or airway responsiveness contrasts with the results obtained with bronchoalveolar lavage fluid, ${ }^{23}$ largely owing to the extreme outlying values from subject 7 , who presented with predominant cough and sputum and had only mildly increased airway responsiveness. This may represent a variant presentation of asthma in which variable airflow obstruction is minimal and airway inflammation is the dominant feature. ${ }^{21}$

The features observed in the sputum of patients with chronic bronchitis, including the predominance of macrophages of altered morphology, the pigmented cytoplasmic inclusions in the macrophages, and the predominance of acid glycoprotein in the mucus, confirm previous reports. ${ }^{1321}$ It was surprising to find no differences in bronchial epithelial cells between the two groups; this, however, may have been due to the fact that only intact and not degenerate epithelial cells were counted.

Thus sputum provides a non-invasive, repeatable method of investigating the pathogenesis of airway disease. Our results suggest that there may be specific characteristics of the inflammatory process in asthma that may be used to validate the diagnosis.

We thank Dr M Dolovich for assistance with patient recruitment and Glaxo Canada Inc for supplying the medications used in this study. PGG is a Boehringer research fellow. This work was supported by the Medical Research Council of Canada.

\section{References}

1 Dunnill MS. The pathology of asthma, with special reference to changes in the bronchial mucosa. $J$ Clin Pathol 1960;13:27-33.

2 Kirby JG, Hargreaves FE, Gleich GJ, O'Byrne PM. Bronchoalveolar cell profiles of asthmatic and nonasthmatic subjects. Am Rev Respir Dis 1987;136: 379-83.

3 Wardlaw AJ, Dunnette S, Gleich GJ, Collins JV, Kay AB. Eosinophils and mast cells in bronchoalveolar lavage in subjects with mild asthma. Relationship to bronchial hyperreactivity. Am Rev Respir Dis 1988; 137:62-9.

4 Brown HM. Treatment of chronic asthma with prednisolone. Significance of eosinophils in the sputum. Lancet 1958;ii:1245-7.

5 Baigelman W, Chodosh S, Pizzuto D, Cupples LA. Sputum and blood eosinophils during corticosteroid treatment of acute exacerbations of asthma. Am J Med 1983;75:929-36.

6 Kimura I, Tanizaki Y, Saito K, Takahashi K, Veda N, Suto S. Appearance of basophils in the sputum of patients with bronchial asthma. Clin Allergy 1975; 1:95-8.

7 O’Connell JM, Baird LI, Campbell AH. Sputum eosinophilia in chronic bronchitis and asthma. Respiration 1978;35:65-72.

8 Vieira VG, Prolla JC. Clinical evaluation of eosinophils in the sputum. J Clin Pathol 1979;32:1054-7.

9 Turnbull LS, Turnbull LW, Leitch AG, Crofton JW, Kay AB. Mediators of immediate-type hypersensitivity in sputum from patients with chronic bronchitis and asthma. Lancet 1977; ii:526-9.

10 Cockcroft DW, Killian DN, Mellon JJA, Hargreave FE. Bronchial reactivity to inhaled histamine: a method and clinical survey. Clin Allergy 1977;7:235-43.

11 Okuda M, Ohtsuka H, Kawabori S. Basophil leukocytes and mast cells in the nose. Eur J Respir Dis 1983; 64(Suppl 128):7-14.

12 Otsuka H, Denburg J, Dolovich J, et al. Heterogeneity of metachromatic cells in human nose: significance of human mast cells. J Allergy Clin Immunol 1985;76: 695-702.

13 Salvato G. Some histological changes in chronic bronchitis and asthma. Thorax 1968;23:168-72.

14 Kramer MS, Feinstein AR. Clinical biostatistics. LIV. The biostatistics of concordance. Clin Pharmacol Ther 1981;29:111-23.

15 Chodosh S, Zaccheo CW, Segal MS. The cytology and histochemistry of sputum cells. Am Rev Respir Dis 1962;85:635-48.

16 Huber HL, Koessler KK. The pathology of bronchial asthma. Arch Intern Med 1922;30:689-760.

17 Denburg JA, Otsuka H, Ohnishi M, Ruhno J, Bienenstock J, Dolovich J. Contribution of basophil/mast cell and eosinophil growth and differentiation to allergic tissue inflammatory response. Int Arch Allergy Appl Immunol 1987;82:321-6.

18 Otsuka H, Dolovich J, Richardson M, Bienenstock J, Denburg JA. Metachromatic cell progenitors and specific growth and differentiation factors in human nasal mucosa and polyps. Am Rev Respir Dis 1987; 136:710-77.

19 Schulman ES, Kagey-Sobotka A, MacGlashan DW, et al. Heterogeneity of human mast cells. J Immunol 1983;131:1936-41.

20 Dvorak AM, Schleimer RP, Lichtenstein LM. Human mast cells synthesise new granules during recovery from degranulation. In vitro studies with mast cells purified from human lungs. Blood 1988;71:76-85.

21 Hargreave FE, Gibson PG, Girgis-Gabardo A, et al. Asthmatic airway inflammation without airway hyperresponsiveness to methacholine [abstract]. $J$ Allergy Clin Immunol 1989;83:A295.

22 Warr GA, Martin RR. Histochemical staining and in vitro spreading of human pulmonary alveolar macrophages: variability with cigarette smoking status. $J$ Reticuloendothelial Soc 1978;23:53-62. 